\title{
Correlation of Ventilation-Perfusion (V/Q) Scan Results as Compared with Clinical Probability of Pulmonary Embolism in African American Population
}

\author{
Fasil Tiruneh ${ }^{1}$, Ahmad Awan ${ }^{2}$, Nicole Hunt ${ }^{1}$, Nahom Tegegn ${ }^{1}$, DANIEL A. LARBI ${ }^{3}$ \\ 1. Department of Internal Medicine, Howard University Hospital 2. Department of Internal Medicine, \\ Howard University Hospital, Washington DC, USA 3. Department of Internal Medicine, Howard \\ University Hospital, Washington, USA
}

$\square$ Corresponding author: Fasil Tiruneh, fasment2000@gmail.com

Disclosures can be found in Additional Information at the end of the article

\section{Abstract}

Introduction

Current guidelines suggest the use of the more specific Wells' score could safely reduce the number of unnecessary scans. There is a lack of research to support whether these guidelines apply to the African American population. This study aims to evaluate the correlation of clinical pretest probability of pulmonary embolism (PE) with ventilation-perfusion (V/Q) scan results in a predominantly African American population and to test whether current guidelines based on studies conducted in other populations hold true in this group.

Material and Methods

A retrospective descriptive study to determine the diagnostic utility of the V/Q scan was conducted among patients who were seen during January 2012 to January 2016. The study population included patients who underwent a V/Q scan for evaluation of PE. One hundred and seventy-five charts were reviewed and 49 were excluded due to poor quality data. A review of the initial history, as well as discharge summaries, was performed. Wells' probability of PE was compared with the results of the scan. Laboratory tests and imaging studies were reviewed and analyzed.

Result

Received 05/26/2017

Review began 06/02/2017 Review ended 06/12/2017 Published 06/14/2017

\section{(c) Copyright 2017}

Tiruneh et al. This is an open access article distributed under the terms of the Creative Commons Attribution License CC-BY 3.0., which permits unrestricted use, distribution, and reproduction in any medium, provided the original author and source are credited.
The median age of the study population was $63.02 \pm 16.12$ years. The majority of the study population, 121 patients (92.4\%), was African American. Sixty-four (48.9\%) VQ scans were done for a low clinical probability for pulmonary embolism as defined by the Wells' clinical score. The most common clinical presentations were shortness of breath (SOB) - 74 (58\%), leg pain or swelling - 39 (29.8\%), chest pain - 36 (27.4\%), and syncope - 4 (3.1\%). Sixty-two (96.9\%) patients with low clinical probability had low probability VQ scans $(\mathrm{P}=0.03)$. Among the patients who underwent CT angiography and V/Q scanning, a low probability scan was noted in 25 patients with no pulmonary embolism on CT $(96.2 \%)(\mathrm{P}=0.006)$.

Conclusions

This study showed a strong correlation between low clinical probability and low probability V/Q
How to cite this article

Tiruneh F, Awan A, Hunt N, et al. (June 14, 2017) Correlation of Ventilation-Perfusion (V/Q) Scan Results as Compared with Clinical Probability of Pulmonary Embolism in African American Population. Cureus 9(6): e1353. DOI 10.7759/cureus.1353 
scans and its utility to safely rule out PE in a predominantly black population. Studies conducted in other populations have detected similar findings.

Categories: Cardiology, Internal Medicine, Pulmonology

Keywords: pulmonary embolism, african-american, wells clinical probability, ventilation-perfusion (v/q) scan

\section{Introduction}

Ventilation-perfusion (V/Q) scans are ordered primarily to assess the probability of acute pulmonary embolus. This study is preferable over computerized tomography angiography (CTA) for patients with contrast allergy, renal failure, or those too large for the CT gantry or bed. This study may also be preferable in young patients (especially women) due to lesser radiation dose and those with clear lungs on x-ray [1].

The clinical probability of pulmonary emboli (PE) should be considered when factoring in V/Q scan interpretations as pre-imaging probability affects the accuracy of the interpretation. The most common clinical criteria for determining the pre-imaging probability of PE is the Wells' score. Many clinicians consider a negative d-dimer result, combined with a low-pretest probability of PE by the Wells' criteria, to be negative for acute PE, thus preventing the need for further assessment using imaging [2-3].

A high-probability scan usually indicates a pulmonary embolism, but only a minority of patients with pulmonary embolism have a high-probability scan. A history of pulmonary embolism decreases the accuracy of diagnoses based on high probability scans. A lowprobability scan with a strong clinical impression that pulmonary embolism is not likely makes the possibility of pulmonary embolism remote. Near-normal/normal lung scans make the diagnosis of acute pulmonary embolism very unlikely. An intermediate-probability (indeterminate) scan is not of help in establishing a diagnosis. In the Prospective Investigation of Pulmonary Embolism Diagnosis (PIOPED) study, the scan, combined with clinical assessment, permitted a noninvasive diagnosis or exclusion of acute pulmonary embolism for a minority of patients [4].

\section{Materials And Methods}

A retrospective descriptive study to determine the diagnostic utility of V/Q scan was conducted among patients who were seen between January 2012 to January 2016. Ethical clearance to conduct the research was granted by the Office of Regulatory Research Compliance of Howard University (approval \#FW A00000891).

The study population included patients who underwent a V/Q scan for evaluation of pulmonary embolism. One hundred and seventy-five charts were reviewed and 49 were excluded due to poor quality data. A review of the initial history and physical progress notes, as well as discharge summaries, was performed. Clinical presentation and Wells' probability of pulmonary embolism were compared with the results of the scan. Laboratory tests, including d-dimer, as well as imaging studies, including CTA and Doppler studies, were reviewed and analyzed.

\section{Results}

We collected data on 131 patients who underwent V/Q scan for evaluation of pulmonary embolism. The median age of the study population was $63.02 \pm 16.12$ years. However, the age ranges between 15 and 96 years. The majority of the study population (121 patients) (92.4\%) was African American with a male to female ratio of 0.8. Ethnicity was not seen to influence the 


\section{Cureus}

result of the study [Table 1].

\begin{tabular}{|c|c|c|c|c|c|}
\hline & & $\begin{array}{l}\text { Low probability V/Q } \\
\text { scan } n(\%)\end{array}$ & $\begin{array}{l}\text { Intermediate probability } \\
\text { V/Q scan } n(\%)\end{array}$ & $\begin{array}{l}\text { High probability V/Q } \\
\text { scan } n(\%)\end{array}$ & $\begin{array}{l}\text { Total } \\
\mathrm{n}(\%)\end{array}$ \\
\hline \multirow[t]{2}{*}{ GENDER } & Male & 51 (92.7\%) & $2(3.6 \%)$ & 2 (3.6\%) & $\begin{array}{l}55 \\
(100.0 \%)^{a}\end{array}$ \\
\hline & Female & $67(94.4 \%)$ & $1(1.4 \%)$ & $3(4.2 \%)$ & $\begin{array}{l}71 \\
(100.0 \%)\end{array}$ \\
\hline \multirow{4}{*}{ ETHNICITY } & $\begin{array}{l}\text { African } \\
\text { American }\end{array}$ & $108(93.1 \%)$ & $3(2.6 \%)$ & $5(4.3 \%)$ & $\begin{array}{l}116 \\
(100.0 \%)^{b}\end{array}$ \\
\hline & Hispanic & $6(100.0 \%)$ & $0(0.0 \%)$ & $0(0.0 \%)$ & $\begin{array}{l}6 \\
(100.0 \%)\end{array}$ \\
\hline & White & 3 (100.0\%) & $0(0.0 \%)$ & $0(0.0 \%)$ & $(100.0 \%)$ \\
\hline & Others & $1(100.0 \%)$ & $0(0.0 \%)$ & $0(0.0 \%)$ & $\begin{array}{l}1 \\
(100.0 \%)\end{array}$ \\
\hline
\end{tabular}

TABLE 1: Demographic Distribution of Patients Ethnicity and Gender by Result of V/Q Scan

The table shows 108 African Americans (93.1\%) have a low probability V/Q scan. High probability V/Q scan was noted in five African American patients $(4.3 \%)(P=0.71)$.

V/Q: ventilation-perfusion scans; a: P-value 0.71 ; b: P-value 0.99; n: number

Sixty-four (48.9\%) V/Q scans were done for a low clinical probability for pulmonary embolism as defined by the Wells' clinical score. High probability Wells' score was noted among 15 of the patients (11.5\%) for whom a V/Q scan was performed. The high probability V/Q scan was observed in more females than males (4.2 and 3.6\%, respectively). However, the difference was not statistically significant $(\mathrm{P}=0.71)$.

The most common clinical presentations were shortness of breath (SOB) in 74 patients (58\%), leg pain or swelling in 39 patients (29.8\%), chest pain in 36 patients (27.4\%), and syncope in four patients (3.1\%). Recent immobilization in 14 patients (11.9\%), previous deep venous thrombosis (DVT) in 22 patients (12.2\%), and a history of malignancy in 15 patients (2.2\%) were observed. One patient $(0.8 \%)$ had hemoptysis, but this was noted to be rare among patients who underwent a V/Q study to rule out PE. Leg swelling was noted on physical examination in 39 patients (29.8\%). PE was the number one diagnosis in 27 patients (20\%) prior to the scan (Table 2) (Figure 1). 


\section{Cureus}

\begin{tabular}{|c|c|c|c|c|c|}
\hline & & $\begin{array}{l}\text { Low probability } \\
\text { V/Q scan n (\%) }\end{array}$ & $\begin{array}{l}\text { Intermediate probability } \\
\text { V/Q scan } n(\%)\end{array}$ & $\begin{array}{l}\text { High probability } \\
\text { V/Q scan } n(\%)\end{array}$ & $\begin{array}{l}\text { Total n } \\
\text { (\%) }\end{array}$ \\
\hline \multirow{7}{*}{$\begin{array}{l}\text { CLINICAL } \\
\text { PRESENTATION }\end{array}$} & SOB & $66(89.2 \%)$ & $3(4.1 \%)$ & $5(6.8 \%)$ & $\begin{array}{l}74 \\
(100.0 \%)^{a}\end{array}$ \\
\hline & $\begin{array}{l}\text { Leg pain or } \\
\text { swelling }\end{array}$ & $36(92.3 \%)$ & $1(2.6 \%)$ & $2(5.1 \%)$ & $\begin{array}{l}39 \\
(100.0 \%)^{b}\end{array}$ \\
\hline & Chest pain & $36(100.0 \%)$ & $0(0.0 \%)$ & $0(0.0 \%)$ & $\begin{array}{l}36 \\
(100.0 \%)\end{array}$ \\
\hline & $\begin{array}{l}\text { SOB and } \\
\text { Chest pain }\end{array}$ & $9(100.0 \%)$ & $0(0.0 \%)$ & $0(0.0 \%)$ & $\begin{array}{l}9 \\
(100.0 \%)\end{array}$ \\
\hline & Syncope & $4(100.0 \%)$ & $0(0.0 \%)$ & $0(0.0 \%)$ & $\begin{array}{l}4 \\
(100.0 \%)\end{array}$ \\
\hline & $\begin{array}{l}\text { Altered } \\
\text { mental status }\end{array}$ & $2(100.0 \%)$ & $0(0.0 \%)$ & $0(0.0 \%)$ & $\begin{array}{l}2 \\
(100.0 \%)\end{array}$ \\
\hline & Hemoptysis & $1(100.0 \%)$ & $0(0.0 \%)$ & $0(0.0 \%)$ & $\begin{array}{l}1 \\
(100.0 \%)^{\mathrm{C}}\end{array}$ \\
\hline
\end{tabular}

\section{TABLE 2: Clinical Presentation of Patients by Results of V/Q scans}

The most common clinical presentation was SOB, leg pain/swelling, chest pain, and syncope. No statistically significant differences were noted between individual presenting symptoms and V/Q scan results.

V/Q: ventilation-perfusion scans; SOB: shortness of breath

P-values: a: 0.81 , b: $0.90 ;$ c: 0.96

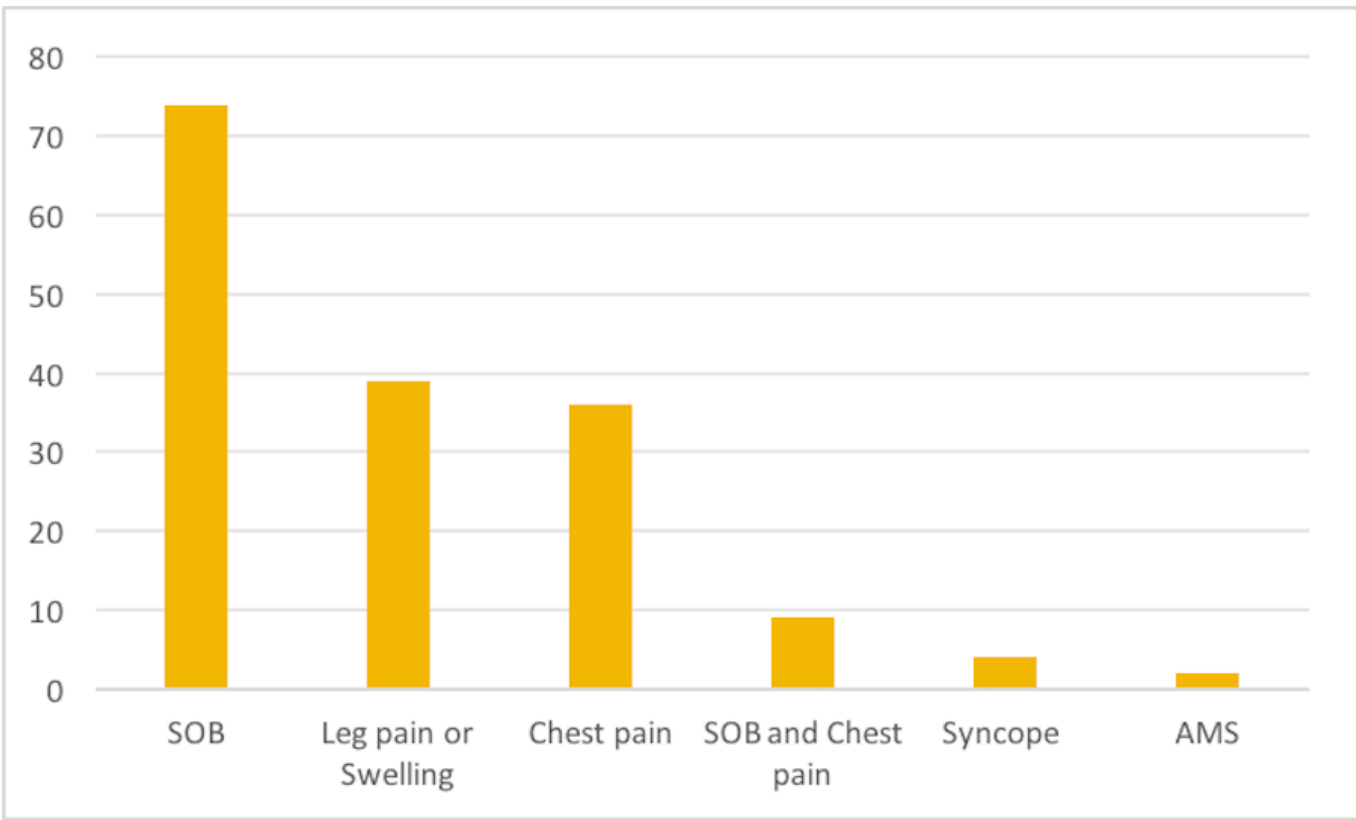




\section{FIGURE 1: Bar chart showing frequency of clinical presentation of study population}

SOB: shortness of breath

Among patients with a high clinical probability of pulmonary embolism by the Wells' criteria, shortness of breath was the main presenting symptom. More than half (58.8 \%) of high probability scans were done for patients with shortness of breath. A high probability scan result was not seen among patients who presented with chest pain alone. However, the observation was not statistically significant $(\mathrm{P}=0.88)$. Tachycardia was noted in four of five patients $(80 \%)$ of high probability $\mathrm{V} / \mathrm{Q}$ scans as compared to one out of 20 patients (5\%) with normal heart rate $(\mathrm{P}=0.003)$.

The study showed no statistically significant difference between recent immobilization and $\mathrm{V} / \mathrm{Q}$ scan results $(\mathrm{P}=0.67)$. A previous history of malignancy was associated with a higher number of intermediate and high probability V/Q scans as compared with patients with no history of malignancy (18.8\% vs $4.5 \%$, respectively), and the difference was noted to be statistically significant $(\mathrm{P}=0.03)$. A low probability scan was noted in 105 patients $(95.5 \%)$ with no previous history of malignancy versus 13 patients (81.3\%) with a previous malignancy. A higher occurrence of high probability V/Q scan was observed in patients with previous history of DVT (9.1\%) as compared with no previous DVT (2.9\%). However, the association was not significant $(\mathrm{P}=0.64)$. Among patients with pulmonary embolism as the primary diagnosis, $88 \%$ had a low probability scan, while a $95 \%$ low probability scan was seen in patients with other diagnoses $(\mathrm{P}=0.12)$ (Table 3). 


\section{Cureus}

\begin{tabular}{|c|c|c|c|c|c|}
\hline & & $\begin{array}{l}\text { Low probability } \\
\text { V/Q scan } n(\%)\end{array}$ & $\begin{array}{l}\text { Intermediate } \\
\text { probability V/Q scan n } \\
\text { (\%) }\end{array}$ & $\begin{array}{l}\text { High probability } \\
\text { V/Q scan n (\%) }\end{array}$ & $\begin{array}{l}\text { Total } \\
\text { n (\%) }\end{array}$ \\
\hline \multirow{2}{*}{ Heart Rate } & Normal heart rate & $0(0.0 \%)$ & $1(1.2 \%)$ & $85(100.0 \%)$ & $86(100 \%)$ \\
\hline & Tachycardia & $1(3.4 \%)$ & $4(13.8 \%)$ & $29(100.0 \%)$ & $\begin{array}{l}34 \\
(100 \%)^{a}\end{array}$ \\
\hline \multirow[t]{2}{*}{$\begin{array}{l}\text { Recent } \\
\text { Immobilization }\end{array}$} & No immobilization & $93(93.0 \%)$ & $3(3.0 \%)$ & $4(4.0 \%)$ & $\begin{array}{l}100 \\
(100.0 \%)^{b}\end{array}$ \\
\hline & $\begin{array}{l}\text { Recent } \\
\text { immobilization }\end{array}$ & $12(92.3 \%)$ & $0(0.0 \%)$ & $1(7.7 \%)$ & $\begin{array}{l}13 \\
(100.0 \%)\end{array}$ \\
\hline \multirow[t]{2}{*}{$\begin{array}{l}\mathrm{H} / \mathrm{O} \\
\text { Malignancy }\end{array}$} & No malignancy & $105(95.5 \%)$ & $2(1.8 \%)$ & $3(2.7 \%)$ & $\begin{array}{l}110 \\
(100.0 \%)^{c}\end{array}$ \\
\hline & $\begin{array}{l}\text { History of } \\
\text { malignancy }\end{array}$ & $13(81.3 \%)$ & $1(6.3 \%)$ & $2(12.5 \%)$ & $\begin{array}{l}16 \\
(100.0 \%)\end{array}$ \\
\hline $\begin{array}{l}\text { H/O Previous } \\
\text { DVT }\end{array}$ & No previous DVT & 97 (94.2\%) & $3(2.9 \%)$ & $3(2.9 \%)$ & $\begin{array}{l}103 \\
(100.0 \%)^{d}\end{array}$ \\
\hline \multirow{3}{*}{ Diagnosis } & Previous DVT & $20(90.9 \%)$ & $0(0.0 \%)$ & $2(9.1 \%)$ & $\begin{array}{l}22 \\
(100.0 \%)\end{array}$ \\
\hline & $\begin{array}{l}\text { PE not as number } \\
\text { one diagnosis }\end{array}$ & $96(95.0 \%)$ & $1(1.0 \%)$ & $4(4.0 \%)$ & $\begin{array}{l}101 \\
(100.0 \%)^{e}\end{array}$ \\
\hline & $\begin{array}{l}\text { PE as number one } \\
\text { diagnosis }\end{array}$ & $22(88 \%)$ & $2(8 \%)$ & $1(4 \%)$ & $25(100 \%)$ \\
\hline
\end{tabular}

\section{TABLE 3: Clinical Presentation of Patients by Results of V/Q Scans}

No statistically significant difference was found between recent immobilization and VQ scan result $(p=0.689)$. A previous history of malignancy was associated with a higher number of intermediate and high $(p=0.031)$.

DVT: deep vein thrombosis; PE: pulmonary embolus; V/Q: ventilation-perfusion scans.

p-Values: a: 0.003; b: 0.689; c: 0.031; d: 0.648; e: 0.12

Only 10 patients (8.5\%) with low probability VQ scan had a high clinical probability for pulmonary embolism. Sixty-two patients (96.9\%) with low clinical probability had a low probability V/Q scan. Three (23.1 \%) patients with high clinical probability had an intermediate or high probability V/Q scan. Patients with moderate Wells' scores were noted to have low probability scan in $93.9 \%$ and a high probability scan in $6.1 \%$. Differences seen with clinical Wells' scores were statistically significant $(\mathrm{P}=0.03)$ (Table 4) (Figures 2-3). 


\section{Cureus}

\begin{tabular}{|c|c|c|c|c|c|}
\hline & & $\begin{array}{l}\text { Low Probability } \\
\text { V/Q scan n (\%) }\end{array}$ & $\begin{array}{l}\text { Intermediate Probability } \\
\text { V/Q scan n (\%) }\end{array}$ & $\begin{array}{l}\text { High Probability V/Q } \\
\text { scan n (\%) }\end{array}$ & $\begin{array}{l}\text { Total } \\
\mathrm{n}(\%)\end{array}$ \\
\hline \multirow{3}{*}{$\begin{array}{l}\text { Wells' } \\
\text { score }\end{array}$} & $\begin{array}{l}\text { Low clinical } \\
\text { probability }\end{array}$ & 62 (96.9\%) & $2(3.1 \%)$ & $0(0.0 \%)$ & $\begin{array}{l}64 \\
(100.0 \%)^{\mathrm{a}}\end{array}$ \\
\hline & $\begin{array}{l}\text { Moderate clinical } \\
\text { probability }\end{array}$ & 46 (93.9\%) & $0(0.0 \%)$ & $3(6.1 \%)$ & $\begin{array}{l}49 \\
(100.0 \%)\end{array}$ \\
\hline & $\begin{array}{l}\text { High clinical } \\
\text { probability }\end{array}$ & 10 (76.9\%) & $1(7.7 \%)$ & $2(15.4 \%)$ & $\begin{array}{l}13 \\
(100.0 \%)\end{array}$ \\
\hline
\end{tabular}

\section{TABLE 4: Correlation Between the Clinical Pretest Probability with V/Q Scan}

\section{Probability}

Sixty-two patients $(96.9 \%)$ with low clinical probability had a low probability V/Q scan $(P=0.03)$.

V/Q: ventilation-perfusion scans; P-value a: 0.03

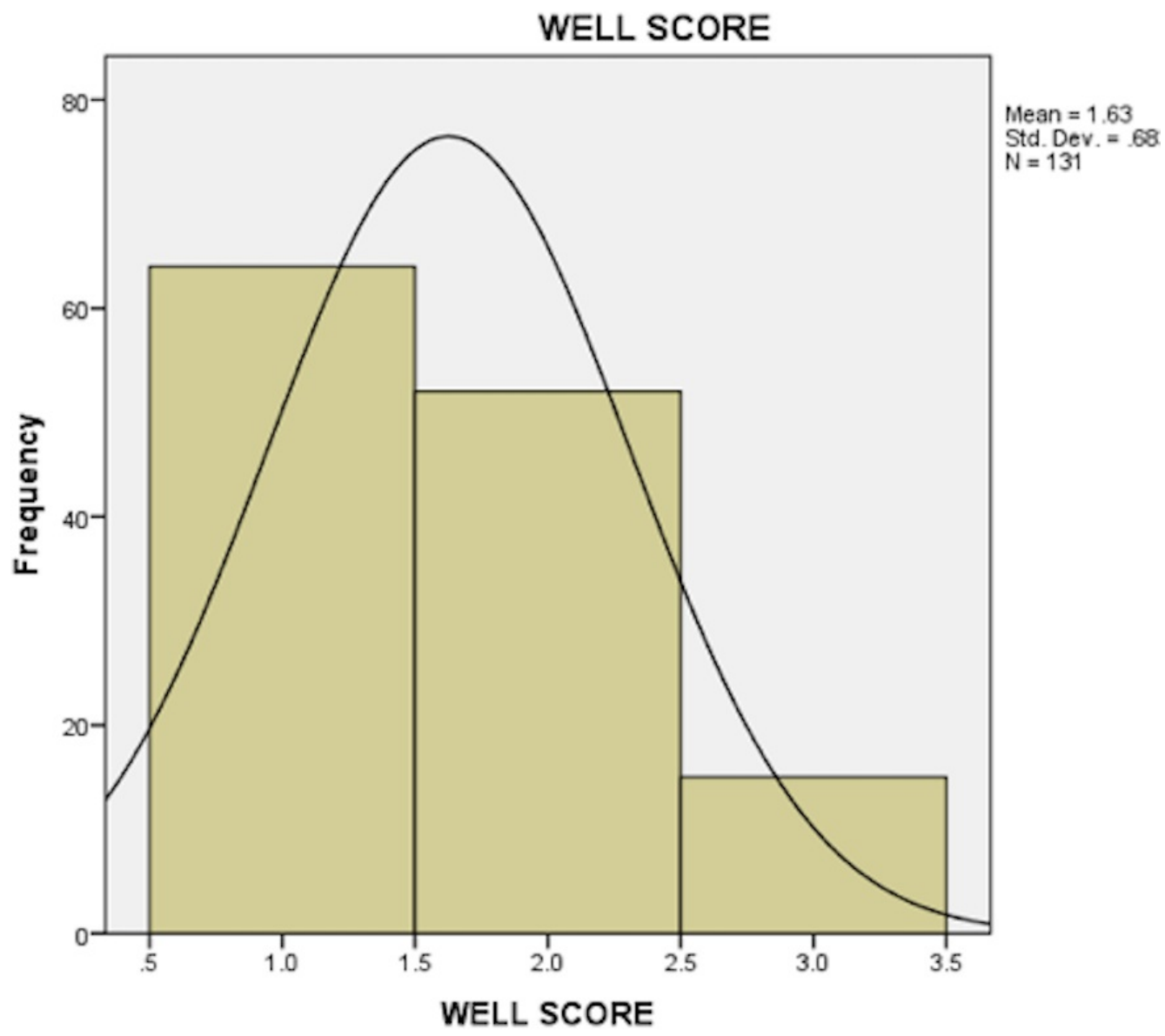

FIGURE 2: Bar chart showing the frequency of Wells' score results among the study population 


\section{Cureus}

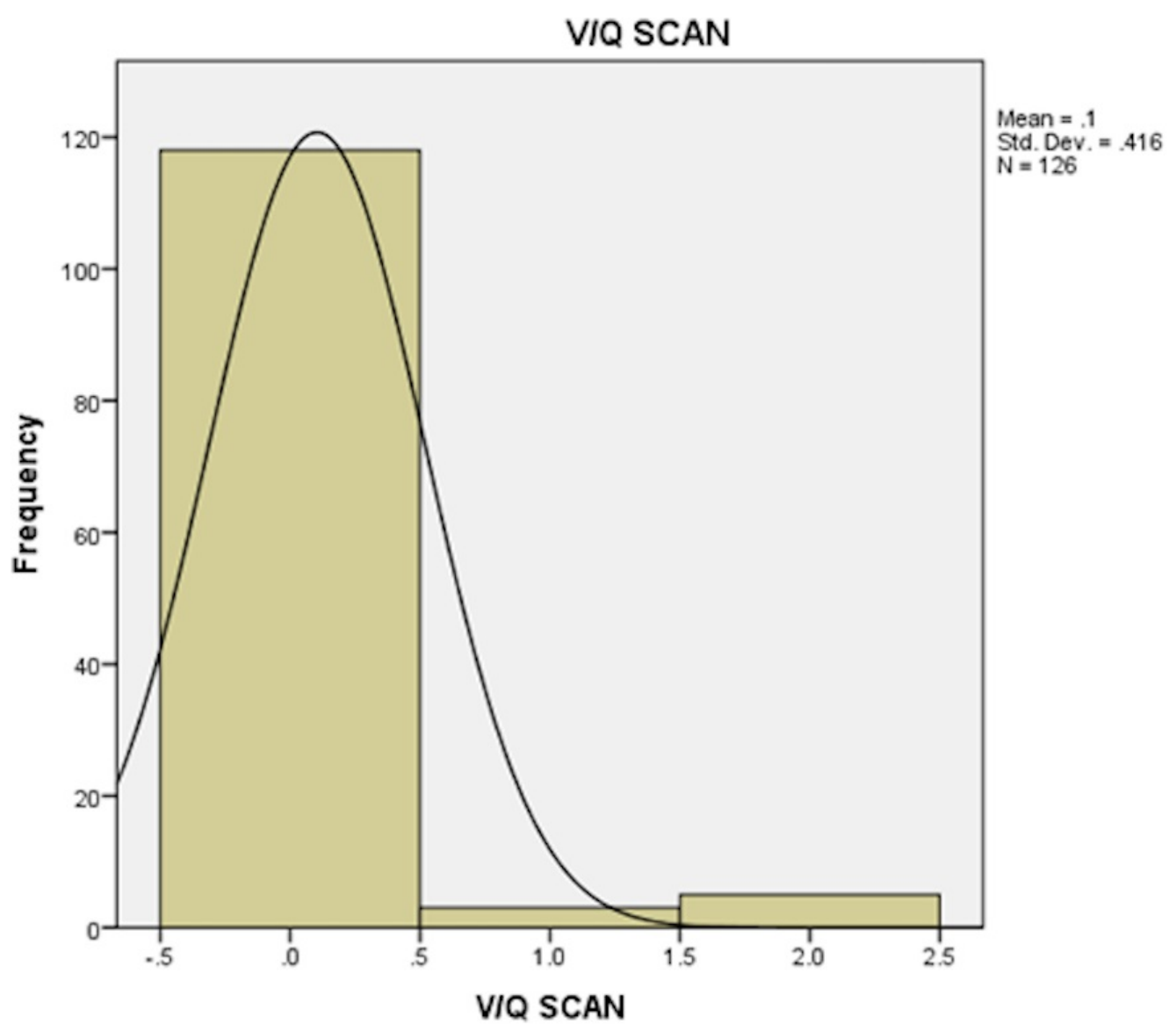

FIGURE 3: Bar chart showing the frequency of V/Q scan results among the study population

V/Q: ventilation-perfusion

No clear association was noted between a troponin level and V/Q scan probability. The majority of patients with intermediate and high probability scans have no leukocytosis (94 (82.1\%) vs 21 $(17.9 \%)(\mathrm{P}=0.71)$ ). Elevated creatinine levels of greater than or equal to $1.5 \mathrm{mg} / \mathrm{dl}$ were seen in $74 / 117$ (63.5\%) of the study population and were the main indication to prefer a V/Q scan to rule out PE as opposed to CTA. D-dimer test was done in 43/131 patients. Among patients with normal d-dimer tests, the result of the V/Q scan was a low probability in $100 \%$. Elevated ddimer tests were reported in $38 / 43$ (89.4\%) of patients in which $7.3 \%$ showed intermediate or high probability $\mathrm{V} / \mathrm{Q}$ scan $(\mathrm{P}=0.82)$.

The presence of deep venous thrombosis (DVT) on Doppler ultrasound was another parameter that was assessed with the results of VQ scans. In 62 patients (47.7\%), a Doppler scan to rule out DVT was done prior to the scan and was positive in 11 (8.5\%) of the patients. Of the patients with DVT, $9.1 \%$ had a high probability V/Q scan versus $4 \%$ in patients with no DVT (P $=0.76)$ (Table 5). 


\section{Cureus}

\begin{tabular}{|c|c|c|c|c|c|}
\hline & & $\begin{array}{l}\text { Low probability V/Q } \\
\text { scan } n(\%)\end{array}$ & $\begin{array}{l}\text { Intermediate probability } \mathrm{V} / \mathrm{Q} \\
\text { scan } \mathrm{n}(\%)\end{array}$ & $\begin{array}{l}\text { High probability V/Q } \\
\text { scan n (\%) }\end{array}$ & $\begin{array}{l}\text { Total n } \\
(\%)\end{array}$ \\
\hline \multirow[t]{2}{*}{$\begin{array}{l}\text { D- } \\
\text { Dimer }\end{array}$} & $\begin{array}{l}\text { Not } \\
\text { elevated }\end{array}$ & $5(100.0 \%)$ & $0(0.0 \%)$ & $0(0.0 \%)$ & $\begin{array}{l}5 \\
(100.0 \%)^{\mathrm{a}}\end{array}$ \\
\hline & Elevated & 38 (92.7\%) & $2(4.9 \%)$ & $1(2.4 \%)$ & $\begin{array}{l}41 \\
(100.0 \%)\end{array}$ \\
\hline \multirow[t]{3}{*}{$\begin{array}{l}\text { Doppler } \\
\text { US }\end{array}$} & No DVT & $46(92.0 \%)$ & $2(4.0 \%)$ & $2(4.0 \%)$ & $\begin{array}{l}50 \\
(100.0 \%)^{b}\end{array}$ \\
\hline & DVT & $10(90.9 \%)$ & $0(0.0 \%)$ & $1(9.1 \%)$ & $\begin{array}{l}11 \\
(100.0 \%)\end{array}$ \\
\hline & No PE & 25 (96.2\%) & $1(3.8 \%)$ & $0(0.0 \%)$ & $\begin{array}{l}26 \\
(100.0 \%)^{c}\end{array}$ \\
\hline \multirow[t]{6}{*}{$\begin{array}{l}\text { CT } \\
\text { Finding }\end{array}$} & Pneumonia & $4(100.0 \%)$ & $0(0.0 \%)$ & $0(0.0 \%)$ & $4(100 \%)$ \\
\hline & Effusion & $4(100.0 \%)$ & $0(0.0 \%)$ & $0(0.0 \%)$ & $4(100 \%)$ \\
\hline & COPD & $1(50.0 \%)$ & $0(0.0 \%)$ & $1(50.0 \%)$ & $2(100 \%)$ \\
\hline & ILD & $1(100.0 \%)$ & $0(0.0 \%)$ & $0(0.0 \%)$ & $\begin{array}{l}1 \\
(100.0 \%)\end{array}$ \\
\hline & PE & 2 (66.7\%) & $0(0.0 \%)$ & $1(33.3 \%)$ & $\begin{array}{l}3 \\
(100.0 \%)\end{array}$ \\
\hline & $\begin{array}{l}\text { Limited } \\
\text { study }\end{array}$ & $2(66.7 \%)$ & $1(33.3 \%)$ & $0(0.0 \%)$ & $\begin{array}{l}3 \\
(100.0 \%)\end{array}$ \\
\hline
\end{tabular}

TABLE 5: Correlation Between D-dimer, DVT, and CTA Findings as Compared with V/Q Scan Probability

High probability scans were noted in $33.3 \%$ of patients who had a positive computed tomography angiography for pulmonary embolism $(P=0.006)$.

COPD: chronic obstructive pulmonary disease; CT: computed tomography; DVT: deep vein thrombosis; ILD: interstitial lung disease; PE: pulmonary embolus; US: ultrasound; V/Q: ventilation-perfusion scans

P-values: a: 0.82; b: 0.76; c: .0.006

CT of the chest was done in 44 patients (42.7\%) following a negative VQ scan, and pneumonia and pleural effusion were the commonest diagnoses made. On the other hand, limited studies were accountable for ordering a VQ scan in three of the cases (2.5\%). Pulmonary embolism was noted in $2.5 \%$ of patients who had a V/Q scan. Among patients who underwent CTA and V/Q scan, a low probability scan was noted in patients with no pulmonary embolism on CTA in 25 (96.2\%). A high probability scan was noted in $33.3 \%$ of patients who had positive CT 
angiography for pulmonary embolism. The difference was statistically significant $(\mathrm{P}=0.006)$ (Table 5).

\section{Discussion}

The advantages of the V/Q scan are a lower radiation dose than computed tomography pulmonary angiogram (CTPA) and the lack of need for iodinated contrast; therefore, V/Q scanning is often considered as the preferred alternative chest imaging to CTPA. The effective radiation dose from a V/Q scan is $1.4 \mathrm{mSv}$ compared to $10-12 \mathrm{mSv}$ from routine CTPA [5-6]. The clinical probability assessment using the Wells' score provides greater accuracy in estimating the clinical probability score, independent of clinician's experience, and allows the option for alternative diagnosis. A study by Wells, et al. showed a pretest probability of low in 734 patients (3.4\% with pulmonary embolism), moderate in 403 (27.8\% with pulmonary embolism), and high in 102 (78.4\% with pulmonary embolism) [7].

In the PIOPED II study, new dyspnea at rest or on exertion was the most frequent symptom in patients with pulmonary embolism and no prior cardiopulmonary disease (73\%). Similarly, our study also showed dyspnea to be the commonest clinical presentation. Immobilization (bedrest within past month for the most of the day for $\geqslant$ three consecutive days) was the most frequent risk factor assessed in patients with pulmonary embolism. In our study, recent immobilization was noted in 12/105 patients. Among all patients with pulmonary embolism, calf swelling, plus pain with palpation of the deep veins, occurred in $32 \%$. Our study also showed a relatively higher occurrence of high probability scan among patients with leg pain or swelling (5.1\% vs $2.1 \%$ ) [8]. Similar to our study population where hemoptysis was the least presenting symptom, in both the PIOPED and PIOPED II studies, hemoptysis, when present, occurred only in small amounts [9].

A study by Barghouth, et al. suggested low V/Q scan probability associated with low clinical probability could exclude PE in 43/45 cases (96\%). In our study, the pretest probability was low in $96.6 \%$ of the low probability scans. This was consistent with most other studies demonstrating a strong correlation between low clinical probability and low probability V/Q scans and its utility to safely rule out PE. However, there was a relatively higher number of low probability scans (93.7\%) than the Barghouth, et al., study (57\%) [10]. Although the sensitivity of the d-dimer test is high, the specificity is not sufficiently high enough for the test to be diagnostic; however, $\mathrm{d}$-dimer is a valuable tool in the exclusion of $\mathrm{PE}$, as the negative predictive value of d-dimer is high [11].

A possible limitation of our study is the low prevalence of pulmonary embolism in our sample; this may suggest that most of the patients were at lower risk. Data recording was also not optimal in some patients. It is possible that the results of our study may not apply to a patient population with a higher prevalence of thromboembolic disease. However, it is expected to hold true in a population with a low probability of pulmonary embolism.

\section{Conclusions}

Using the accepted guidelines in which a high pretest probability leads to further imaging and a low probability leads to a d-dimer blood test, use of the more specific Wells' score could safely reduce the number of unnecessary scans. The PIOPED II investigators recommend stratification of all patients with suspected pulmonary embolism according to an objective clinical probability assessment. Our study has reflected the importance of a negative d-dimer test combined with a low or moderate clinical probability to rule out PE. However, no statistically significant correlation was observed between elevated d-dimer and results of a V/Q scan. In view of this finding, we suggest other possible diagnoses should be explored, even in patients with elevated d-dimer tests. 


\section{Additional Information}

\section{Disclosures}

Human subjects: Consent was obtained by all participants in this study. Office of Regulatory Research Compliance, Howard University issued approval FW A00000891. Animal subjects: All authors have confirmed that this study did not involve animal subjects or tissue. Conflicts of interest: In compliance with the ICMJE uniform disclosure form, all authors declare the following: Payment/services info: All authors have declared that no financial support was received from any organization for the submitted work. Financial relationships: All authors have declared that they have no financial relationships at present or within the previous three years with any organizations that might have an interest in the submitted work. Other relationships: All authors have declared that there are no other relationships or activities that could appear to have influenced the submitted work.

\section{Acknowledgements}

The authors would like to acknowledge Dr. Julius Ngwa for his input in the statistical analysis.

\section{References}

1. Roach PJ, Bailey DL, Harris BE: Enhancing lung scintigraphy with single-photon emission computed tomography. Semin Nucl Med. 2008, 38:441-49. 10.1053/j.semnuclmed.2008.06.002

2. Ramzi DW, Leeper KV: DVT and pulmonary embolism: Part I. Diagnosis . Am Fam Physician. 2004, 69:2829-36.

3. Wells PS, Anderson DR, Rodger M, et al.: Excluding pulmonary embolism at the bedside without diagnostic imaging: management of patients with suspected pulmonary embolism presenting to the emergency department by using a simple clinical model and d-dimer. Ann Intern Med. 2001, 135:98-107. 10.7326/0003-4819-135-2-200107170-00010

4. PIOPED Investigators: Value of the ventilation/perfusion scan in acute pulmonary embolism. Results of the prospective investigation of pulmonary embolism diagnosis (PIOPED). JAMA. 1990, 263:2753-59. 10.1001/jama.1990.03440200057023

5. ICRP Publication 60: 1990 Recommendations of the International Commission on Radiological Protection, 1st Edition. (1991). Accessed: June 8, 2017: http://www.icrp.org/publication.asp?id=ICRP\%20Publication\%2060.

6. Administration of Radioactive Substances Advisory Committee: Notes for Guidance on the Clinical Administration of Radiopharmaceuticals and Use of Sealed Radioactive Sources, March 2006. Health Protection Agency, Great Britain; 2006.

7. Wells PS, Ginsberg JS, Anderson DR, et al.: Use of a clinical model for safe management of patients with suspected pulmonary embolism. Ann Intern Med. 1998, 129:997-1005. 10.7326/0003-4819-129-12-199812150-00002

8. Stein PD, Beemath A, Matta F, et al.: Clinical characteristics of patients with acute pulmonary embolism: data from PIOPED II. Am J Med. 2007, 120:871-79. 10.1016/j.amjmed.2007.03.024

9. Stein PD, Saltzman HA, Weg JG: Clinical characteristics of patients with acute pulmonary embolism. Am J Cardiol. 1991, 68:1723-24. 10.1016/0002-9149(91)90339-M

10. Barghouth G, Yersin B, Boubaker A, et al.: Combination of clinical and V/Q scan assessment for the diagnosis of pulmonary embolism: A 2-year outcome prospective study. Eur J Nucl Med. 2000, 27:1280-85. 10.1007/s002590000284

11. Douma RA, le Gal G, Söhne M, et al.: Potential of an age adjusted D-dimer cut-off value to improve the exclusion of pulmonary embolism in older patients: a retrospective analysis of three large cohorts. BMJ. 2010, 340:c1475. 10.1136/bmj.c1475 